ISCKMC 2020

International Scientific Congress «KNOWLEDGE, MAN AND CIVILIZATION»

\title{
IMAGE TRANSFORMATION OF THE RESOURCE TYPE REGION DURING CLUSTER DEVELOPMENT OF CULTURE
}

\author{
Natalya Vasilyevna Kostyuk (a)*, Viktor Ivanovic Markov (b), \\ Anastasia Sergeevna Telmanova (c), Zulfiya Mansurovna Akhmetgaleeva (d), \\ Tatyana Aleksandrovna Volkova (e) \\ *Corresponding author
}

(a) Kemerovo State Institute of Culture, 47, V. Voloshina Str., apt. 17, Kemerovo, Russia, kostuk1978@mail.ru (b) Kemerovo State Institute of Culture, 30, Volgogradskaya Str., apt. 24, Kemerovo, Russia, vikt-markov@yandex.ru

(c) Kemerovo State Institute of Culture, 146, Lenin Ave., apt. 121, Kemerovo, Russia, astel-75@mail.ru.

(d) Kemerovo State Institute of Culture, 164, Lenin Ave., apt. 81, Kemerovo, Russia, zula_a@inbox.ru (f) Kemerovo State Institute of Culture, 43, Khimikov Ave., apt. 53, Kemerovo, Russia, tatyanaolkowa@yandex.ru

\begin{abstract}
The paper presents the results of the search for attractors to transform the image of the coal mining Kuzbass region as a resource type region, which development is affected by external and internal factors. The most striking factors include a decrease in the role of the coal industry for the region and the creation of a powerful cultural cluster, one of four clusters in the Russian Federation. The study is focused on the search and scientific substantiation of the effective mechanisms for implementation of the strategy for the socioeconomic development of Kemerovo region until 2035, Development of human capital in terms of the strategic priorities Comfortable environment - a new quality of life and Traditions of Kuzbass - new opportunities. The identified priorities are inextricably linked to the social changes in the conditions of active development of the scientific and technological complex of the region. The paper provides a theoretical substantiation of the phenomenon of the image of the region, which affects the cultural space of the region as well as socio-cultural preferences and needs of the population. It also considers conceptualization of the image transformation as a necessary process for the cultural and socio-economic development of the region imposed by historical conditions. To determine and clarify the specifics of the region in the context of cluster development of culture, an empirical study was carried out based on the analysis of statistical data for Kemerovo region.
\end{abstract}




\section{Introduction}

The socio-cultural transformations and studies of coal mining regions, with their special cultural space and the decreased volume and role of coal mining in the modern world, are relevant not only in the Russian Federation but also in a number of regions of Western and Eastern Europe, Great Britain and others. In Russia, it is associated with the creation of a powerful cultural cluster in one of the Siberian regions (Kuzbass). The cluster is one of the four clusters in the country, which is formed, from a socio-cultural viewpoint, to increase the general cultural level in the region and to ensure the entry of Kuzbass into the world of a modern, diversified economy and culture.

In the modern post-industrial era, culture is defined as a strategic resource for the development of the identity of the state in terms of the spiritual equivalent, and for the formation of a qualitatively new sphere of economic relations in terms of the production and consumption of cultural goods.

A cluster approach to the development of cultural and creative initiatives of local communities has been formed in the context of market relations in society and state regulation of the cultural sphere. At the same time, the creation of such spaces in the urban environment is associated with economic benefits that imply the production and consumption of material goods, the creation of new jobs and the development of urban infrastructure (Tsang \& Siu, 2016). Modern literature covers the problems of cluster and reflects the aspects of the economic efficiency of the cluster development of culture in terms of the economic consequences of cultural revival and the development of tourism as an effective industry ensuring the sociocultural viability of the region (Pourzakarya \& Bahramjerdi, 2019).

Prospects for the development of cultural clusters in the Russian Federation are specified in the decree of the President of Russia On national goals and strategic objectives of development of the Russian Federation in the period until 2024. As part of implementation of the tasks, the geography of cultural clusters was determined, including five strategically important regions, Kemerovo region among them (MK $\mathrm{RF}, 2019)$.

It should be noted that the strategy for state regulation of the cluster development of culture cannot guarantee its sustainable functioning, since the cultural level of the population is not taken into account. A number of foreign scientists note that 'Demographic, cultural and socio-economic variables, namely age, marital status, income, education, and family size, are the key factors affecting consumer's behavior', including the consumption of a cultural product (Shashi et al., 2015).

\section{Problem Statement}

The image of a resource-type region is an attractor for development of the socio-cultural space in the region, taking into account the socio-demographic characteristics of the population of Kuzbass as subjects of this space. The highlighted problem is interdisciplinary and multilevel, which determines its complexity. 


\section{Research Questions}

The image of a resource-type region is a complex phenomenon studied at the intersection of various scientific areas, which exhibits multidisciplinarity in terms of the possibilities of its practical application in social life (philosophy, sociology, social psychology, cultural studies, political science, etc.).

1. What are the general prerequisites for formation, interpretation and transformation of the image in the context of various scientific disciplines, historical development, socio-economic and political status of the region?

2. What are the socio-demographic characteristics of the population of a resource type region as subjects of the socio-cultural space that provide a multidirectional interpretation of the image of the region?

\section{Purpose of the Study}

Analysis of the phenomenon of the image of a resource type region on the example of Kemerovo region (Kuzbass) and drawing up a socio-demographic 'portrait' of a resident of Kuzbass as a subject of the socio-cultural space of the region, who contributes to the interpretation and translation of the image components.

\section{Research Methods}

To provide a unified methodological platform and scientific substantiation of the study, a set of the following approaches and methods was used:

- partially systematic approach - to identify the elements of consistency in the cultural space of the region;

- activity-based approach - to consider the historical types of economic activity that have shaped the modern image of the region;

- historical-genetic method - to consider the current cultural situation in the region as a result of its long-term development;

- semiotic method - to identify structural components and semantic content of the image of the region as viewed by its residents;

- a set of statistical methods (statistical observation, analysis of variance, summary and grouping of statistical observation materials, cross-tabulation, cluster analysis) - to create a general sociodemographic image of the region (Bryman, 2004).

\section{Findings}

\subsection{The essence and interpretation of the concept of 'image' as an attractor for development} of the socio-cultural space of the region

The concept of image, which is the key concept in this study, has many nuances and interpretations, and is very controversial. Note only some features of interpretation of the concept of image which are necessary to solve the problem stated and not to carry out a purely conceptual analysis. 
In the modern world, the image is initially perceived as a purely subjective phenomenon that reflects certain opinions, ideas, visual images of an individual, society, nation (Abdieva \& Shaibakova, 2020). At the same time, the image is an artificially constructed phenomenon inherent in mass culture and used for manipulation in politics, advertising, show business. It should be noted that in this case it is only a superficial understanding of the image, which characterizes it as an artificially created epiphenomenon that disappears just as quickly. Specialists make big efforts to create it almost from nothing; therefore, it has almost no objective basis and does not correspond to anything in objective reality.

The image can also be considered less subjectively, as a phenomenon that is quite stable in time and cultural space and is based on the objective basis - an element of a regional cultural tradition. Thus, the following components can be distinguished in the time aspect in the structure of the image of the region:

- image as a historically developed socio-psychological tradition, which imparts its features to the consciousness and behavior of people, often hidden in everyday situations, for example, a national character, which usually revives in critical situations. This is a latent effect of the past (Myslivets \& Romanov, 2018);

- actual image as self-identification of the population and its ideas about its territory at the regional level, which is based on comparison: with the world (as far as it is represented in the media and in people's minds), with neighboring regions (personal experience), etc.;

- expected, desired image as a certain ideal in the movement towards the future, which is based on comparison and previous perception. In fact, it is an attractor in the consciousness and behavior of people.

These provisions emphasize the understanding of the image as a 'product of the mind' of each individual to form the public image of the subject (Belyaev, 2020).

There is another structuring of the image of the region, which from the point of view of social interaction includes:

- official image established and promoted by the authorities through the media;

- the image of the region in the mass consciousness of the majority of the population, which are dominant and privileged in some way and usually support the official image;

- the image of the region associated with self-identification at the individual level, which can be either quite definite or chaotic and eclectic according to the principle: on the one hand, on the other hand (Bicken \& Smbatyan, 2015).

All of the above applies to the internal structure of the image within the region itself. However, since the population actively contact with the outside world, especially with neighboring regions, the image of the region as viewed by the inhabitants of the surrounding territories is of great importance. The information culture, which is in direct interaction with the cultural level of the population, plays a crucial role in shaping the image of the territory. At the same time, it affects the development of the cultural background of the entire region (Gryaznova et al., 2020).

Thus, the image of the region is a complex socio-psychological phenomenon that has an objective basis. It is not always an obvious, but rather significant factor that affects the cultural space of the region and the socio-cultural preferences and needs of the population. 


\subsection{Historical image of the region}

At certain stages, as is typical of elements of the historical and cultural tradition, the previously established image in its various aspects contradicts a number of parameters with the changed socioeconomic conditions, professional and educational level of the population, especially young people. At the same time, constant comparison, identification with the surrounding world and especially with the immediate community, is of great importance.

Based on these considerations, give a brief outline of the historical dynamics of the changing images of the region. Of course, we can judge this mainly on the basis of the official attitudes and documents. However, since these official attitudes were not only promoted, but in certain periods were supported by real privileges, it is logical to assume that they largely reflected the attitude of a significant part of the population.

In order not to go deep into history, confine ourselves to the Soviet period. At the beginning of industrialization of the Soviet state, it was in Kuzbass that a new and powerful industrial center of Russia was established. The geographical location of the region (far from borders and external threats) determined its strategic importance in terms of the industrial potential of the state. The region gave hope for joining the world's most economically powerful countries. However, historical sources describe the dark side of the region's development. Kuzbass became the center of Main Directorate of Camps and Places of Incarceration (GULAG). After release, many prisoners formed the primary backbone of both the population and the miners' stratum (Uymanov, 2016). No doubt, these people had a completely different view of the region's image and they themselves formed the corresponding image.

During the Great Patriotic War, the Kuznetsk territory and the Urals became the country's backbone that ensured victory. This also contributed to the creation of the image of the region.

After the war, the predominant slogan (and, accordingly, the image) was Kuzbass is a mining region, the basis of the country's energy sector, which existed until perestroika and the collapse of the USSR, and until recently in official propaganda. However, in many ways it did not correspond to the mood of the people, especially due to the enormous destruction of the image of the region, which, in connection with the transition from mine to quarry mining, increasingly turned into a land disfigured by mining.

To date, the region is focused on a radical restructuring of the socio-cultural and economic infrastructure, and, on transformation of the perception of the region in mass consciousness. The study addresses the issues of forming a 'different' image of regions, with a prevailing number of single-industry towns, which include Kuzbass. The rapid pace of development and dramatic changes in the industrial development of the state oblige local authorities to increase the attractiveness of the region for local residents and to attract investment in the form of financial and human capital (Fomin et al., 2020).

\subsection{Socio-demographic 'portrait' of a modern resident of Kuzbass}

Fomin et al. (2020) identified the main factors of the vital activity of the regions, which play a decisive role in formation and management of the image of modern settlements and regions. These include: resettlement (population density, ethnic structure); economic and budgetary policy (industries, agriculture, service sector, etc.); demographic situation (reproduction, social problems, age and sex structure of the population); labor market (economic activity, employment); socio-economic situation of households 
(dynamics of money income, purchasing power); quality of life of the population (social security, sports, leisure, safety) (Fomin et al., 2020).

In the study, the factor 'quality of life of the population' was supplemented with the following criterion, which affects the formation of a positive image, especially of the image of a resource type region - a cultural situation, which includes the socio-cultural infrastructure of the region, a regional cultural product, and socio-cultural needs of the population.

Based on the factors, we have compiled a socio-demographic portrait of a resident of Kemerovo region (Kuzbass) in order to determine the prospects and directions for formation of the image of the region in the context of the cluster development of culture.

Resettlement. At present, the population of Kemerovo region (Kuzbass) is 2,674,256 people, which is $15.6 \%$ of the population of the Siberian Federal District and $1.8 \%$ of the population of the Russian Federation. It should be noted that the urban population predominates and amounts to $86 \%$. The number of settlements is 210 municipalities, of which: urban districts - 16; municipal districts - 18; urban settlements -22 ; rural settlements -154 . The administrative center is the city of Kemerovo (558.7 thousand people) (Mukhacheva, 2019).

According to the latest population census, representatives of more than 150 peoples (nations, nationalities, ethnic groups) live in Kemerovo region. At the same time, the majority of the population of Kemerovo region are Russians (2,536,646 people). The other most numerous ethnic groups are: Tatar, German, Ukrainian, Armenian, Chuvash, Belarusian, and Azeri.

Kemerovo region is inhabited by the peoples included in the unified list of indigenous smallnumbered peoples of the Russian Federation: Shortz (10,672 people); Teleuts (2,520 people).

On the territory of Kemerovo region, 42 national public associations are registered, which set the task to preserve their native language, national culture, traditions and customs, actively participate in the socio-economic, social, cultural and sports life of the region, provide charitable assistance to senior citizens and veterans, low-income families, orphans, and work with children and youth.

Economic and budgetary policy. The share of industry in the gross regional product of Kemerovo region (Kuzbass) is $58 \%$. On the territory of Kemerovo region, agricultural activities are carried out by 545 agricultural enterprises. The volume of retail trade turnover is 376.6 billion rubles. The region ranks third in the Siberian Federal District in terms of retail trade volume, and 23rd in the Russian Federation.

Demographic situation. To date, the men/women ratio in Kuzbass is $45.9 \%$ and $54.1 \%$, respectively, of which $20 \%$ are younger than working age, $54 \%$ are of working age, and $26 \%$ are older than working age (Table 1).

Table 1. Age and sex composition of the population in Kemerovo region at the beginning of 2019

\begin{tabular}{llll}
\hline & \multicolumn{3}{c}{2019} \\
\hline Total & Both sexes & Men & Women \\
including those aged, years: & 2674256 & 1228157 & 1446099 \\
\hline $0-4$ & & & \\
$5-9$ & 155859 & 79850 & 76009 \\
$10-14$ & 178943 & 91824 & 87119 \\
$15-19$ & 160639 & 82115 & 78524 \\
\hline
\end{tabular}




\begin{tabular}{llll}
\hline $20-24$ & 124255 & 62322 & 61933 \\
$25-29$ & 174318 & 88786 & 85532 \\
$30-34$ & 226109 & 113875 & 112234 \\
$35-39$ & 221695 & 107985 & 113710 \\
$40-44$ & 195935 & 92185 & 103750 \\
$45-49$ & 172320 & 80505 & 91815 \\
$50-54$ & 148569 & 68476 & 80093 \\
$55-59$ & 197566 & 86991 & 110575 \\
$60-64$ & 195265 & 79986 & 115279 \\
$65-69$ & 157017 & 59478 & 97539 \\
$70-74$ & 82174 & 28106 & 54068 \\
$75-79$ & 61662 & 17160 & 44502 \\
80 and older & 91037 & 21935 & 69102 \\
\hline of which those: & & \\
\hline - younger than able-bodied population (men and women & 524956 & 268937 & 256019 \\
aged 0-15 years). & & \\
- able-bodied population (men aged 16-59 years, women & 1451570 & 752555 & 699015 \\
aged 16-54 years old). & & & \\
- older than able-bodied population (men aged 60 and & 697730 & 206665 & 491065 \\
older, women aged 55 and older). & & \\
\hline
\end{tabular}

Labor market. The number of labor force in 2019 amounted to 1,291.2 thousand people, including $1,220.4$ thousand people employed in the economy, and 70.8 thousand unemployed people who actively looked for work (according to the methodology of the International Labor Organization, they are classified as unemployed). The employment rate of the population was $55.6 \%$, and the unemployment rate was 5.5 $\%$. The average age of the employed population in 2019 was 40.8 years (in $2018-40.5$ years). More than half of the employed population were people aged 30 to 50 (56.7\%), people aged 15 to 30 years old amounted to $18.6 \%$, and those aged over 60 years old amounted to $5.9 \%$.

Socio-economic characteristics of households. The structure of household expenditures in 2019 included the purchase of goods and payment for services $-77 \%$ (taking into account the volume of payments for goods (work, services) to foreign suppliers for non-cash and cash payments); compulsory payments and other expenses $-15 \%$; increase in savings $-8 \%$. The housing-and-municipal and telecommunications services prevailed in the volume of paid services and amounted to $47.7 \%$ of the total volume (Table 2).

Table 2. The structure of use of money income by the population in 2019 (in percent)

\begin{tabular}{ccccc}
\hline & \multicolumn{4}{c}{ Amount of money income spent on: } \\
\hline & Money income & goods and services & $\begin{array}{c}\text { compulsory } \\
\text { payments and other } \\
\text { expenses }\end{array}$ & $\begin{array}{c}\text { increase in } \\
\text { savings }\end{array}$ \\
\hline quarter I & 100 & 79.3 & 15.3 & 5.4 \\
quarter II & 100 & 74.8 & 14.3 & 10.9 \\
quarter III & 100 & 79.0 & 14.9 & 6.0 \\
quarter IV & 100 & 73.6 & 15.7 & 10.7 \\
2019 & 100 & 76.5 & 15.1 & 8.4 \\
2018 (as a reference) & 100 & 76.6 & 14.8 & 8.6 \\
\hline
\end{tabular}


According to the Federal State Statistics Service in Kemerovo region, the average income in Kemerovo region (Kuzbass) in 2019 amounted to 24,415 rubles per month (5\% more than in 2018), while expenses were 18,676 rubles per month (5\% more than in 2018).

The quality of life of the population. Kuzbass ranked 54 (out of 85) in the Rating of Russian regions on quality of life (RIA, 2019). It should be noted that Kuzbass remains one of the criminogenic regions of the Russian Federation. The crime rate in the region in 2019 amounted to 611 registered crimes per 100,000 people, which is higher than the crime rate in the Siberian Federal District.

In terms of the prospects for the cluster development of culture in Kuzbass, we studied the cultural situation in the region, which determines the modern image of Kuzbass and the modern portrait of a resident of this region. Defining the socio-cultural infrastructure as an organic unity of institutions of culture, education, information, recreation, sports and state (regional, local) cultural policy, which are formed to meet the needs and interests of representatives of all categories of the population within a single geographic unit (Telmanova \& Yudina, 2014), we focused on the involvement of the population in the social and cultural life of Kuzbass.

According to the Ministry of Physical Culture and Sports of Kuzbass, in 2019 1,119 thousand people were involved in physical culture and sports, or 44.5 percent of the population of Kemerovo region. Currently, there are 8,445 sports facilities in Kemerovo region with a one-time capacity of 215.8 thousand people, including 27 stadiums with 1.5 thousand seats and more, 1,066 gyms, 123 swimming pools, 4,484 sports facilities, and 107 municipal sports organizations (74,906 people) (Kuprina et al., 2019).

The cultural space in the region is represented by 7 theaters and the state autonomous cultural institution of Kuzbass Kemerovo State Regional Philharmonic named after B.T. Shtokolov, 43 museums, 613 public libraries, 577 institutions of cultural and leisure type, and 108 cinemas.

Analysis of statistical data showed that in 2019 3,725 performances and concerts were performed in Kemerovo region and attended by 773.2 thousand people. A total of 1,118,231 readers visited Kuzbass libraries in 2019 (municipal libraries - 896,939 people, rural libraries -221,292 people). The number of people who visited public library sites amounted to $1,910,980$ people. The number of visits to public library events was about 1.8 million. In 2019, Kuzbass museums were visited by 1,119.8 thousand people.

Cultural events involve all segments of the population, which emphasizes their social orientation and interest in formation of a cultural product that meets the socio-cultural needs of the population.

In 2018, 70,268 events were organized for children (up to 14 years old), which were attended by 39,699 children. In addition, cultural institutions of the region held 49,116 youth cultural events (from 14 to 24 years old), which were visited by $3,976,172$ people. A total of 22,049 events were organized for family leisure, and the number of visitors amounted to 5,447,959 people; 13,949 events were held for citizens of the older generation, which were attended by 2,076,599 representatives of the older generation. Special attention was paid to disabled people. In 2018, 5,670 events for people with disabilities were held in the region, and 460,791 people were involved in the events (Tables 3, 4). 
Table 3. Number of visits to cultural events as of January 01, 2019

\begin{tabular}{|c|c|c|c|c|c|c|}
\hline & $\begin{array}{l}\text { Total } \\
\text { number of } \\
\text { cultural } \\
\text { events }\end{array}$ & $\begin{array}{l}\text { Number of } \\
\text { visits to } \\
\text { cultural } \\
\text { events }\end{array}$ & $\begin{array}{l}\text { Number of } \\
\text { cultural and } \\
\text { leisure } \\
\text { activities }\end{array}$ & $\begin{array}{l}\text { Number of } \\
\text { visits to } \\
\text { cultural and } \\
\text { leisure } \\
\text { activities }\end{array}$ & $\begin{array}{c}\text { Number of } \\
\text { educational } \\
\text { outreach } \\
\text { events }\end{array}$ & $\begin{array}{l}\text { Number of } \\
\text { visits to } \\
\text { educational } \\
\text { outreach } \\
\text { events }\end{array}$ \\
\hline By cities & 49565 & 14173747 & 42440 & 13350636 & 7125 & 823111 \\
\hline $\begin{array}{c}\text { By } \\
\text { districts }\end{array}$ & 122144 & 7452287 & 108526 & 6692841 & 13618 & 759446 \\
\hline Total & 171709 & 21626034 & 150966 & 20043477 & 20743 & 1582557 \\
\hline
\end{tabular}

Table 4. The number of visits to cultural events on a fee basis as of January 01, 2019

\begin{tabular}{ccccccc}
\hline & $\begin{array}{c}\text { Total } \\
\text { number of } \\
\text { cultural } \\
\text { events on a } \\
\text { fee basis }\end{array}$ & $\begin{array}{c}\text { Number of } \\
\text { visits to } \\
\text { cultural } \\
\text { events }\end{array}$ & $\begin{array}{c}\text { Number of } \\
\text { cultural and } \\
\text { leisure } \\
\text { activities }\end{array}$ & $\begin{array}{c}\text { Number of } \\
\text { visits to } \\
\text { cultural and } \\
\text { leisure } \\
\text { activities }\end{array}$ & $\begin{array}{c}\text { Number of } \\
\text { educational } \\
\text { outreach } \\
\text { events }\end{array}$ & $\begin{array}{c}\text { Number of } \\
\text { visits to } \\
\text { educational } \\
\text { outreach } \\
\text { events }\end{array}$ \\
\hline $\begin{array}{c}\text { By cities } \\
\text { By }\end{array}$ & $\begin{array}{c}17263 \\
\text { districts }\end{array}$ & 3562909 & 15737 & 3362696 & 1526 & 200213 \\
Total & 51462 & 1523936 & 33758 & 1459308 & 441 & 64628 \\
\hline
\end{tabular}

Education is also important for formation and development of the image of the region, therefore we analyzed the state of art education in Kemerovo region (Kuzbass). The culture industry of Kuzbass is represented by 1 university, which is under the jurisdiction of the Ministry of Culture of the Russian Federation, 5 professional educational institutions and 1 institution of additional professional education under the jurisdiction of the Department of Culture and National Policy of Kemerovo region, 106 children's art schools that are under the jurisdiction of municipalities. In 2019, the Siberian branch of the Central Music School, Moscow State Tchaikovsky Conservatory, was opened in the region.

The increased number of children going to art schools indicates the need for this type of education among children and adolescents.

At the beginning of 2019-2020 academic year, students of professional educational institutions in the sphere of culture in Kemerovo region amounted to 1,353 people; the number of students enrolled in bachelor's, specialist's and master's programs of higher education was 2,182 people.

\section{Conclusion}

Coal mining regions are a serious problem for many countries around the world in terms of socioeconomic parameters. In continental Western Europe, for example, its mass production becomes largely unacceptable for environmental reasons, its price falls, and the economic efficiency of coal mining decreases. Kuzbass is not an exception. However, from a socio-cultural point of view, the situation in Kuzbass is somewhat different than in the countries of the Western world. This is due to a number of factors that affect the perception and interpretation of the image of the region by its residents and external observers. 
Firstly, according to the Soviet ideology, the working class is the most advanced class in society, and miners are the heroic vanguard of the working class. This official propaganda was largely perceived by a significant part of the local population and affected the mass consciousness of the country. Indeed, in terms of working conditions, coal mining (and it was the main one) is truly heroic work. Moreover, this image of miners' work and Kuzbass as a whole was reinforced by the central government through a number of privileges for the local population and especially for miners. The privileges included high salaries and special supply to meet the needs of local population, which was of great importance in the conditions of goods deficit.

Secondly, as a result of disintegration of the country, its ideological foundations and market transformations, the self-identification of miners' work as the pride of the country began to collapse.

Thirdly, a significant part of the population advocated for a change of the socio-economic and cultural image of the region to a more modern and versatile, multicolored one.

Thus, a contradiction arose between the historically formed image and new needs, including the socio-cultural needs of the population.

The analysis of the socio-demographic characteristics of the population of modern Kuzbass enabled assessment of the cultural and social realities that determine the problematic and promising areas of transformation of the socio-cultural needs of the population. In the future, this will become the basis for development of the arts cluster and a strategy for multi-level work with the population of the region, taking into account their current needs, transformations and the state of the local community.

At the same time, the analysis revealed the socio-cultural environment in Kuzbass, which indicates that involvement of the population in events that take place in the socio-cultural space of the region.

Due to the effect of the factors considered in the study, a socio-cultural experiment has been initiated in Kuzbass. This is a kind of 'cultural revolution' to introduce world-class cultural achievements into the cultural space of the region, which used to be proud of the status of 'Miners' Territory' in the form of 'high culture' (ballet, theaters, museums, etc.). At present, this is dictated by the reduced role of coal mining and diversification of the structure of the regional economy. Moreover, this contributes to a change in the population structure, the emergence of new socio-cultural needs, an increase in the level of education, transformation of the image of the region, and creation of the living and cultural conditions for the population of the region, especially for youth.

\section{Acknowledgments}

The study was funded by RFBR and the authorities of Kemerovo region (Kuzbass), project \# 20413-420004.

\section{References}

Abdieva, G. M., \& Shaibakova, D. (2020). The concept 'image' in modern linguo-culture. World of sci., culture, ed., 1(80), 317-320.

Belyaev, V.I. (2020). Reputation, image, brand: creation and use in practice of strategic management of companies and territories. Econ. Profession Busin., 1, 16-27. https://doi.org/10.14258/epb201953 
Bicken, N. S., \& Smbatyan, S. A. (2015). The features of territory image formation. Bull. of the Univer., 10, 292-295.

Bryman, A. (2004). Quantity and Quality in Social Research (Contemporary Social Research). Taylor \& Francis e-Library.

Fomin, M. V., Bezverbny, V. A., Shushpanova, I. S., \& Mikryukov, N. Yu (2020). Company towns of the Siberia and RussianFar East: potential and development prospects. Issues of state and municipal government, 1, 137-165.

Gryaznova, E. V., Treushnikov, I. A., \& Goncharuk, A. G. (2020). The role of information culture in the formation of a cultural ideal. Perspect. of Sci. and Ed., 43(1), 379-388. https://doi.org/10.32744/pse.2020.1.27

Kuprina, I. K., Rumyantseva, E. E., Smirnova, N. V., \& Bahyshov, R. D. O. (2019). Estimation of efficiency of regional policy for the development of physical culture and sports. Bull. of the Acad. of Knowledge, 35(6), 158-164.

MK RF (2019). President of Russia presented projects of cultural clusters in the regions of the Russian Federation. Ministry of Culture News. https://www.mkrf.ru/press/news/prezidentu_rossii_predstavili_proekty_kulturnykh_klasterov_v_re gionakh_rf/?sphrase_id $=2458587$

Mukhacheva, A. V. (2019). Demographic potential of single-industry towns of the Kemerovo region as a component of the quality of life. Bull. of the Kemerovo State Univer., 3, 120-129.

Myslivets, N. L., \& Romanov, O. A. (2018). Historical memory as a socio-cultural phenomenon: experience of sociological reconstruction. RUDN J. of Sociol., 18(1), 9-19. https://doi.org/10.22363/23132272-2018-18-1-9-19

Pourzakarya, M., \& Bahramjerdi, S. (2019). Towards developing a cultural and creative quarter: Cultureled regeneration of the historical district of Rasht Great Bazaar, Iran. Land Use Policy, 89. https://doi.org/10.1016/j.landusepol.2019.104218

RIA (2019). Rating of Russian regions on quality of life Federal State Unitary Enterprise International News Agency Russia Today. https://ria.ru/20190218/1550940417.html

Shashi, A., Kottala, S. Y., \& Singh, R. (2015). A review of sustainability, deterrents, personal values, attitudes and purchase intentions in the organic food supply chain. Pacific Sci. Rev. B: Human. and Soc. Sci., 1(3), 114-123.

Telmanova, A. S., \& Yudina, A. I. (2014). Problems of definition of socio-cultural space. Bull. of the Kemerovo State Univer. of Culture and Arts, 29/1, 149-155.

Tsang, K., \& Siu, K. (2016). The 3Cs model of sustainable cultural and creative cluster: The case of Hong Kong. City, Culture, and Society, 7(4), 209-219. https://doi.org/10.1016/j.ccs.2016.09.001

Uymanov, V. N. (2016). Special movers in the system of the Siberian ITL (SIBLAG) OGPU-NKVD in the 1930s. Innovat. Sci., 2, 58-66. 